\title{
Türkiye'de Önlisans Sağlık Meslekleri Eğitimi 35 Yaşında: Sevgiçiçeği Açan Tarlalardan, Portakal Çiçeği Kokan Bereketli Topraklara Kısa Bir Să̆lık Meslekleri Ĕğitimi Tarihi Yolculuğu
}

\author{
Associate Degree Health Professions Education in Turkey is 35 Years Old: \\ A Short History of Health Professions Education From Fields that Bloom Love Flowers to the \\ Fertile Soils Smelling Orange Flowers
}

Rüştü TAŞTAN

öz

Yirmibirinci yüzyılın değişim dinamiklerinin etkin olduğu, eğitim yöntemleri ve iletişimin küreselleştiği günümüzde, Türkiye'deki sağlık hizmetleri bu sürekli değişimin ve evrensel etkileşim rüzgârının dışında kalamaz kuşkusuz. Bu çalışmada, Türkiye'deki sağlık eğitim hizmetlerinde geçmişi 35 yılı bulan Sağgllk Hizmetleri Meslek Yüksekokulları (SHMYO)'nın niteliksel gelişim ve değişim öyküsü gün yüzüne çıkarılmaktadır.

$\mathrm{Bu}$ amaçla, ülkemizde Önlisans Sağl1k Meslekleri Eğitimi (ÖSME)'nin evrensel standartlara ulaşması için, ulusal standartları önemseyen, "standartsızlıkları" dert edinen sağlık meslekleri eğitimcilerinin gelişim sürecine katkılarına tanıklı̆̆ım vurgulanmaktır.

$\mathrm{Bu}$ çalışmada, Başkent Ankara'dan "ortak akıl hareketi” olarak yola çıkarak Türkiye üniversitelerini dolaşmayı amaçlayan, fakat bir türlü süreklilik kazanamayan, Sağlık Hizmetleri Meslek Yüksekokulları Sempozyumları (SHMYOS)'nın canlandırılması önerilmekte ve mesleklerarası potansiyel birleştirici gücü vurgulanmaktadır. Sağlık hizmetlerinde kalite, maliyetlerde ekonomik kazanım ve 'insancıl bir sağlık hizmeti' ancak eğitilmiş, sosyokültürel yönüyle zenginleştirilmiş, değer verilen sağlık çalışanlarıyla mümkündür.

Türkiye'de sağlık hizmetlerinde özlenen standart, kalite ve yüksek katma değer için, yenilikçilik ve sürdürülebilirlik için; çağdaş bilgi, beceri nitelikleri yüksek, saygı duyulan Sağlık Teknikerleri yetiștiren ÖSME öncelikli olarak ele alınmalı ve her yönüyle desteklenmelidir.

Sonuç olarak, Türkiye'nin geleceği için "sosyal-strateji" ve sağlı ekonomisi bakımından yaygın öneme sahip ÖSME sorunlarının çözümüne giden yol, meslekler arası yeni eğitim iş birlikteliklerinden, evrensel gelişmeleri değerlendirmekten, daha etkin ve yetkin bir tutumla yeni dinamiklere yönelerek, yönetim ve organizasyon yaklaşımlarını güncellemekten geçmektedir. ÖSME sorunlarını çözüm yolu, nitelik ve verimlilik bakımından tam donanımlı, yetkin sağlık insangücü ile "insancıl sağlık hizmetleri sunulması" için eleştirel düşünce eğitimine önem veren öğretim programlarında işlevsellik kazandırmaktan geçmektedir.

Anahtar kelimeler: Ön lisans, sağlık eğitimi, Sağlık Hizmetleri Meslek Yüksekokulu

Rüştü TAŞTAN ( $\square)$

Kocaeli Üniversitesi, Kocaeli Sağllk Hizmetleri Meslek Yüksekokulu

Tibbi Laboratuvar Teknikleri Programı

Umuttepe Merkez Yerleşkesi, 41380 İmit/KOCAELI

e-posta: rtastan@kocaeli.edu.tr / rustu_tastan@yahoo.com.tr

\section{ABSTARCT}

Today, as the dynamics of change in the twenty-first century are effective and education methods and communication are increasingly being global, health services in Turkey can no doubt remain outside this constant change and universal interaction wind. The aim of this paper is to display the story of qualitative development and change of the Vocational School of Health Services(VSHS), which has a history of 35 years in the health education services in Turkey.

This paper aims to emphasize personal testimony to the contributions made by health professions educators, who attach importance to national standards and concerns about "standardlessness", to the development process of the universities, in order to make of the Associate Degree Health Professions Education (ADHPE) in our country meet the universal standards.

This paper proposes the revival and emphasizes the interprofessionally unifying potential power of the Symposiums of Health Service Vocational Schools, which initially aimed to miove around the different universities of Turkey starting from the capital Ankara as a "common mind movement", but somehow failed to maintain a continuous character. Maintainance of quality in health services, economic gains in costs and 'humanitarian health service' are only possible with trained, socioculturally enriched and appreciated health workers.

To maintain the long-awaited standard, quality and high value added in health care services in Turkey, and to attain innovation and sustainability; ADHPE, with a high level of contemporary knowledge, skill, and respect for Health Technicians should be prioritised and supported in every aspect.

As a result, the solution to the problems of ADHPE, which matters for "social-strategy" and health-economical aspects for Turkey's future, is based on creating new interprofessional educational coopereations, appreciating universal developments and updating the managerial and organizational approaches by focusing on new dynamics in a more effective and competent way. The solution to the ADHPE problems is to provide functionality of the critical thinking education within the curriculum in order to "provide humane healthcare services" with competent health manpower fully equipped in terms of quality and efficiency.

Keywords: Associate's degree, health education, Vocational School of Health Services 


\section{Giriş}

"Karşılaştı̆̆ımız önemli sorunlar, onları yarattığımız zaman sahip olduğumuz aynı düzeydeki düşünceyle çözülemez."

\section{Albert Einstein}

Yirmibirinci yüzyılın değişim dinamiklerinin etkin olduğu, üstünlük kazandığı, bilişim, yönetim, eğitim yöntemlerinin ve iletişimin küreselleştiği günümüzde, dünyanın gelişmiş ülkelerinde süregeldiği gibi, Türkiye'deki sağlık hizmetleri de bu sürekli değişim, evrensel etkileşim rüzgârının dışında kalamaz kuşkusuz. Yüzlerce enfeksiyöz ve enfeksiyöz olmayan hastalığın laboratuvar tanısı, gözlem ve taramalarında her geçen gün önemi artan moleküler tanı yöntemleri birçok yeniliği beraberinde getirmekle kalmamış, tanımlanan yeni hastalıklar, yeni mesleklerin doğmasına ve yeni eğitim uygulamalarının yaygınlaşmasına yol açmıştır. Bu devinim ya da dinamizm her geçen gün daha etkinleşmekte ve etkileri çok yönlü yaygınlaşmakta, daha fazla meslekler arası (1) veya disiplinler arası işbirliği yaklaşımını zorlamaktadır. Süregelen bu "yenilenmeci kasırganın" etkileşim yelpazesindeki günümüz sağlık hizmetleri, bilimsel yöntem ve yönelimler, yeni eğitim teknolojileri, yeni bilişimsel uygulamalar, kaçınılmaz olarak sağlık sistemine kazandırılmakta ve her düzeyde sağlık eğitiminde yeni yaklaşımlara yönelmeyi zorlamaktadır. Bu başdöndürücü eğitim, bilimsel ve teknolojik gelişmeler dinamizminin yarattığı küresel "yenilenmeci kasırga etkisi” ve süreklilik, Sağlık Meslekleri Eğitimi (SME)'nde değişimlere yol açmakta ve eğitim yönetimi süreçlerini harekete geçirmekte, kalite için yeniliklere "köprüler" kurulmaktadır (2). Günümüzde, evrensel ölçekli değişim, yerel (ülkesel) eğitim yönetiminde de kaçınılmaz olarak sürekliliği ve yenilenmeyi zorunlu kılmaktadır.

$\mathrm{Bu}$ bağlamda, Türkiye'deki sağlık eğitiminin gelişim sürecine baktığımızda, güncel literatür verilerine göre, Önlisans Sağllk Meslekleri Ĕ̈itimi (ÖSME) hazırlıkları ve yasal düzenlemeleri yaklaşık 35 y1l önce gündeme gelmiştir (3). Türkiye'de üniversiter düzeyde ilk Sağlık Hizmetleri Meslek Yüksekokulu'nun (SHMYO) 1983'de, Ankara'da Hacettepe Üniversitesi'nde açıldığı anlaşılmaktadır $(3,4)$. Son yarım yüzyılda, Türkiye'de Önlisans Sağlık Meslekleri Eğitiminin verildiği SHMYO'ları, sağlık hizmetlerinde kalite ve verimliliği artırmak için "nitelikli sağlık insangücü" gereksinimi karşılamak amacıyla kurulan Yükseköğretim Kurumları olarak varlık göstermektedirler (4). Türkiye'de Yükseköğretim Sistemini düzenleyen 2547 sayılı Yükseköğretim Kurulu(YÖK) yasasında yapılan son değişiklikte Meslek Yüksekokulları(MYO); "Belirli mesleklere yönelik nitelikli insangücü yetiştirmeyi amaçlayan, yılda iki veya ü̧ dönem olmak üzere iki y1llık eğitim-ögretim sürdüren, önlisans derecesi veren yükseköğretim kurumlarıdır." şeklinde tanımlanmaktadır. Ülke genelinde oldukça geniş bir alanda mesleki eğitim hizmeti veren bu mesleki Yükseköğretim kurumları (diğer adıyla SHMYO'ları) yaklaşık 35 yılda, sayıları 200'e yaklaşan devlet ve/veya vakıf üniversitesinde 35 'i aşkın sayıda "diploma programında" Sağlık Meslekleri Eğitimi (SME) verilmesine olanak sunmaktadır $(3,6)$.

Evrensel bilimsel ve teknolojik gelişmelerin 1şı̆̆ında söylenebilir ki; Türkiye'de ÖSME, "Diş Hekimliği, Tıp, Eczacılık, Fizyoterapi, Hemşirelik, Beslenme ve Diyetetik gibi yükseköğrenim programlarının dışında kalan ve sağlık alanında, mesleki yeterlilikler temelinde önlisans düzeyinde eğitim-öğretim verilen, mesleki beceri ve deneyim kazandırılan ve mesleklerini yasal yetkiler çerçevesinde yapabilme sorumluluğunu taşıyan Anestezi, İlk ve Acil Yardım, Tıbbi Görüntüleme, Tıbbi Laboratuvar Teknikeri, Tıbbi Sekreter, Podolog gibi Sağllk Teknikerleri yetiştirilen diploma programlarıdır" $(6,7)$.

Günümüz sağlık sisteminin "nitelikli sağllk insangücü" ihtiyacını karşılamak amacıyla Sağlık Meslekleri Eğitimi verilen SHMYO'larının mezunları, sağlık sektörünün vazgeçilmez mensupları olup, hizmetlerde kalite ve katma değer yarattıkları gibi, aynı zamanda tıbbı teknolojiyi etkin kullanarak hekimlere yardımcı olmaktadırlar. Bu sektörel gereksinmenin bir sonucudur ki, Sağlık Bakanlığınca 2014 yılında yürürlüğe konulan "Sağlık meslek mensupları ile sağlık hizmetlerinde çalışan diğer meslek mensuplarının iş ve görev tanımlarına dair yönetmelik" çerçevesinde hizmet gören Sağllk Teknikerlerinin önemi her geçen gün artmaktadir (7).

Dünyanın pek çok ülkesinde olduğu gibi, ülkemizde de yaygınlaşan sağlık hizmetleri çeşitliliği ve giderek karmaşı hal alan ve çabuk değişen tıbbi teknoloji ve bilişim sistemlerinin yarattığı sonuç olarak geçen yarım yüzyılda "yeni sağlık meslekleri” ortaya çıkmış ve onların çalışmasını belirleyen iş ve görev tanımları yapılmıştır (6). Eğitim sürecinde sayıları, sağlı hizmeti sunumu sürecinde gereksinimi sürekli artı̧ gösteren bu sağlık mesleklerinin bazıları (Tıbbi Laboratuvar Teknikerliği, Illk ve Acil Yardım, Odyometri, Tıbbi Görüntüleme Teknikerliği vb.) ülkemizde 30 yıldan fazla bir zamandır hizmet vermektedir. Fakat yeni gelişen diğer meslekler (Podoloji, Anestezi, Elektronörofizyoloji Teknikerliği vb.) ise son 4-5 yıldır 
çalışma yaşamında kamu ve /veya özel sağlık sektöründe "Sağlık Teknikeri”" unvanıyla varlığını sürdürmektedir (8).

Türkiye'de SHMYO mezunlarının çalışma yaşamındaki görev ve sorumluluklarını tanımlayan yönetmeliğe (7) benzer, sağlık eğitim kurumları veya disiplinler arasında eşgüdümü sağlayan genel bir "tanımlama kılavuzu" veya ÖSME için geliştirilmiş eğitim-öğretim ve uygulamalarını kapsayan "ülkesel standart" henüz oluşturulmamıştır. Yirmibirinci yüzyılın ilk yarısında, gelişmiş ülke sağlık kurumlarında, Sağlık Meslekleri Eğitimi üzerine ve diğer alanlarda (2) bir yandan eğitim modelleri sorgulanıp, "kalite için köprüler" kurulurken, diğer taraftan ÖSME benzeri veya eşdeğeri eğitim kurumlarında eğitim izlenceleri ve içerikleri ile yönetim modelleri yeniden gözden geçirilmekte ve güncellenmektedir. Buna benzer kapsam ve yaklaşımda, Türkiye SHMYO'ları arasında etkin iletişim ve mesleki deneyim paylaşımının olmaması, "ülkesel standartların bulunmaması" ve mevcut eğitim uygulamalarında "bir örneklilik bulunmaması" SHMYO yöneticilerini ve eğitimcilerini geçen 10-12 yılda yeni bir arayışa yöneltmiş ve ortak arayışlara zorlamıştır. Bu "nitelik ve standart arayışının" bir sonucu olsa gerek, ülkemizde ilk SHMYO kuruluşundan yaklaşık 22 yıl sonra ve yine ilk defa Mayıs 2006'da ulusal düzeyde I. Ulusal Sağllk Hizmetleri Meslek Yüksekokulları Sempozyumu (SHMYOS) düzenlenmiştir (9). Bu mesleklerarası bilimsel etkinlik, Türkiye'de, alanında bir ilk olma özelliğini taşımaktadır. SHMYOS, biyolojik kayıtlara göre "nesli tükenmeye yüz tutmuş" ve koruma altına alınmış, hala güzelliğini sürdürerek yaşama renk katan Sevgi çiçeği(10) (Cyanus tchihatcheffii) tarlalarının yakınında, Ankara Gölbaşı’nda, Gazi Üniversitesi SHMYO Müdürlüğünün öncülüğ̈̈nde 11-12 Mayıs 2006 tarihlerinde gerçekleştirilmiştir. $\mathrm{Bu}$ ulusal sağlık eğitimi etkinliği, Türkiye'de ÖSME gelişimi sürecinde "kalite ve standart arayışının" önemli bir başlangıcı olarak sağlık eğitimi tarihindeki yerini almıştır (9). Bu satırların yazarının da etkin katıldığı ve imza attığ 1 'Sempozyum Sonuç Bildirgesi' incelendiğinde, sempozyumda tarihsellik bakımından önem taşıyan görüşlere yer verildiği görülecek ve gelecek öngörüleri, "ortak akıl" potansiyeli (11) nedeniyle her zaman takdir görecektir.

Sempozyum, Gazi Üniversitesi Sağlık Hizmetleri Meslek Yüksekokulu Müdürlüğü tarafindan, 11-12 Mayıs 2006 tarihinde gerçekleştirilen "I.Ulusal Sağllk Hizmetleri Meslek Yüksekokulları Sempozyumu” G.Ü. Gölbaşı Eğitim Tesislerinde (Ankara) yapılmıştır. Sempozyumda 3 açııış konuşması, 1 konferans, 42 sözlü sunum ve 48 poster sunum, toplam 90 katılımcı ile gerçekleştirilmiştir. Bildirilerin büyük bir çoğunluğu SHMYO'nun 'eğitim sorunları ve çözüm önerileri’ üzerine yoğunlaşırken, bir kısmı da çeşitli bilimsel araştırmaları içermektedir." Bu bağlamda, kendi alanında bir ilk olan 1. Ulusal SHMYOS'da dile getirilen bazı temel görüş ve öneriler:

\section{SHMYO'nın Temel Sorunları Olarak Aşağıdaki Maddeler Belirginleşmiştir;}

o Öğrencilerin SHMYO'na sınavsız ve düşük puanla gelmeleri,

o Eğitimde ders birlikteliğinin ve "standardizasyonun sağlanamamış" olması,

o Öğretim elemanı eksikliği,

o Öğretim elemanlarının kalitesinin yükseltilmesi ihtiyacı,

o Pratikten çok teoriğe dayalı eğitimin olması,

o Bina, derslik, laboratuvar ve eğitim araçları eksikliği,

o Uygulama alanı bulmada sorun yaşanması,

o Öğrencilerin SHMYO'larından eğitim dış1 beklentilerinin karşılanamaması

o İş bulma ve iş tanımında yaşanılan problemlerin çokluğu,

o Akademik personel eksikliği ve kalitesi vb. gibi sorunlar siralanmaktadır.

\section{2. Çözüm ve Öneriler Kısmında Yer Verilen Bazı Konular;}

o Öğrenci seçimi ve kaynağının yeniden yapılandırılması,

o Denklikler ve 'standardizasyonun sağlanması' yolunda çalışmalara başlanması

o Koordinasyon ve İşbirliği yapılmalı,

o SHMYO'ların sempozyumlar yaparak hem mesleki sorunların paylaşımı ve giderilmesi, hem de bilimsel etkinliklerin paylaşımı sağlanmalı

o Türkiye'de "Ulusal Sağlık Hizmetleri Meslek Yüksekokulları Koordinatörlüğü” gibi bir sistemin oluşturulması ve YÖK tarafından tanınmasının sağlanması vb. konuların ayrıntılı verildiği Sempozyum Sonuç Bildirgesinin tamamını Gazi Üniversitesi SHMYO Müdürlüğü öğretim kadrosunca 2008 y1lında 
hazırlanan "Geçmişten Geleceğe Sağlık Teknikerliğì" kitabında (11) bulabilirsiniz.

Yirmibirinci yüzyıl eğitim kuramları ve sağlık teknolojilerinin değişken dinamikleri sağlık eğitimine yeni yaklaşım ve yönelimleri gerektirmektedir (2). İletişim ortamlarının ve bilişim teknolojilerinin etki ve dinamizmini doğru değerlendirmek ve hizmetler sürecinde karmaşık olaylar karşısında, beklenmedik tehlike veya krizlerde çözümleyici olabilmeyi sağlamak için sağlık teknikerlerine etkin eleştirel düşünce kazandırılmasının önemi vurgulanmaktadır (12). Bu yeni yaklaşımlar ve önemseme çerçevesinde ÖSME bir bütün olarak değerlendirildiğinde önemli eksikliklerin var olduğu ve süregeldiği görülecektir. Geçen 20-25 yıllık süreçte, ÖSME konusu nitelikten öte, niceliksel değerlendirmelerin olduğu, ağırlıkla "öğrenci ve okul sayılarının dillendirildiği” anlaşılmaktadır. Y1llarca derslik veya laboratuvarlarda eğitsel, yönetsel sorunları gözlemleyen sağlık eğitimcileri tamamen bu yanlışa dur demek, 21.yüzyıla uyum sağlamak için, sorunları gündeme getirmeyi görev saydılar ve ilk Ulusal SHMYOS düzenlemeyi başardılar (9). Birinci sempozyum sonunda alınan kararlar uyarınca, İkinci Ulusal SHMYO Sempozyumunun İzmir Dokuz Eylül Üniversitesinde (13), üçüncü Ulusal SHMYO Sempozyumun Van Yüzüncü Yıl Üniversitesinde (14) yapılmasına oybirliği ile karar verildiği sonuç bildirgelerinden anlaşılmaktadır. Türkiye "sağlık meslekleri eğitimi” tarihinde önemli bir eksikliği giderme potansiyelini bulunduran ve pek çok akademik, sosyokültürel birlikteliklerin, mesleklerarası dostlukların gelişmesini sağlayan, SHMYO'ları öğretim kadroları arasında mesleki bilgi paylaşım köprülerini kurmaya önayak olan bu ikinci sempozyumun sonuç bildirgesini kısaca inceleyelim.

Bildirgenin giriş kısmında "Dokuz Eylül Üniversitesi SHMYO Müdürlüğü tarafından 2-4 Eylül 2007 tarihinde gerçekleştirilen "II. Ulusal Sağlık Hizmetleri Meslek Yüksekokulları Sempozyumu" Dokuz Eylül Üniversitesi Dinlenme ve Eğitim Tesisleri'nde (Doğanbeyİzmir) yapılmıştır. İlk gününde "Eğitimde Ölçme ve Değerlendirme Kursu" verilmiş olan sempozyumun ikinci ve üçüncü günlerinde ise üç panel, 2 konferans ve 1 forum gerçekleştirilmiştir. Sağlık Hizmetleri Meslek Yüksekokullarında eğitim, mesleki eğitimdeki gelişmeler ve yeni yönelimler; sağlık sektörü ile ilişkiler ve mesleki eğitimi geliştirmek için yapılabilecekler ve önerilerin tartışıldığı sempozyuma katılımcılar bildirilerini poster bildiri halinde sunmuşlardır. Sempozyum süresince ve kapanış oturumunda katılımcıların ortak görüş ve kararları doğrultusunda aşağıda belirtilen konularda görüş birliğine varılmıştır." vurgusu yapıldıktan sonra, ikinci kısımda katılımcıların ortak görüşleri 15 madde halinde şöyle özetlenmiştir:

1. Sınavsız geçiş sonrası öğrencilerin giriş bilgileri değişmiş, sınıf başarıları genel olarak düşmüştür. $\mathrm{Bu}$ durumun ele alınarak düzeltilmesi gerekmektedir.

2. Ülke genelinde bir çalışma yapılarak mezunlara olan ihtiyacın ve var olan programlardan gerçekte gereksinim duyulmayanların belirlenmesi uygun olacaktır.

3. Özellikle kamu alanında istihdam sırasında meslek yüksekokulu mezunlarına "kadro önceliği" tanınmalıdır.

4. Çalışma yaşamında SHMYO mezunlarının yetki ve sorumlulukları tam olarak tanımlanmalı, "meslek standartları" ivedilikle tamamlanmalıdır.

5. SHMYO'larında, gerekli fiziksel alt yapı, donanım ve öğretim elemanı sağlanmadan yeni programlar açılmamalıdır.

6. SHMYO'larına eğitim-öğretim programlarına uygun öğretim elemanı kadrosu sağlanmalıdır.

7. SHMYO öğretim elemanlarının kendi eğitimlerine ilişkin etkinliklere katılma ve lisansüstü eğitim yapma olanakları desteklenmelidir.

8. SHMYO'larında uygulama yapılabilecek laboratuvar alt yapı olanaklarının geliştirilmesi gereklidir. Teknolojik gelişime ayak uydurmayı sağlayabilecek eğitim araçları ve laboratuvar donanımları için yeterli bütçe olanakları sağlanmalıdır.

9. Tanımlanan beklentilere uygun olarak, her programdaki kuramsal ve uygulama ders saatleri dengelenmeli ve ülke çapında "eğitimde denklik ve standardizasyonun sağlanması" için çalışma başlatılmalıdır.

10. YÖK bünyesinde Sağlık Hizmetleri Meslek Yüksekokulları arasında ulusal düzeyde eşgüdümü sağlayacak (Koordinatörlük benzeri) bir yapı oluşturulmalıdır.

11. SHMYO'larının ulusal ve uluslararası düzeyde akredite olabilmeleri için çalışmalara ivedilikle başlanmalıdır.

12. Öğretim elemanlarının ya da mezunların gelişimine yönelik Avrupa Birliği Projelerine önem verilmeli, bu konuda çok merkezli girişimler başlatılmalıdır. 
13. SHMYO'larının sektör ile işbirliği ve eşgüdümünü artıracak girişimlere öncelik verilmelidir.

14. SHMYO'ları arasında işbirliği ve paylaşımın artırılması amaciyla düzenli ve sürekli sempozyum, seminer ve benzeri bilimsel etkinlikler yapılması planlanmalıdır.

15. Şubat 2008 'de "eğiticilerin eğitimine" yönelik bir etkinliğin Urfa Harran Üniversitesi SHMYO'nun ev sahipliğinde gerçekleştirilmesine karar verilmiştir. Ayrica, III. Ulusal SHMYO Sempozyumunun Van Yüzüncü Y1l Üniversitesinde, IV. Ulusal SHMYO Sempozyumunun Marmara Üniversitesi tarafindan gerçekleştirilmesine karar verilerek, bu sempozyumlarda "program temelli çalıştayların” yapılması önerilmiştir.

Her üç Ulusal SHMYO Sempozyumu sonuç bildirgelerine dikkatlice bakıldığında, eleştiri ve önerilerde öne çıkan ana konular "hizmetlerde kaliteye, eğitim süreçlerinde standartlaşmaya engel olan ve gelecek için (21. yüzyıl insan sermayesi için) tehdit oluşturan" saptamalar şunlardır: SHMYO arasında paylaşım ve eğitim işbirliklerinin olmaması, sınavsız geçiş sorunları, akademik kalite ve yaklaşımın düşük olması, ulusal ve uluslararası standardın henüz oluşturulmamış olması, YÖK'de SHMYO'larını sevk ve koordine edecek bir birimin (Ulusal SHMYO Koordinatörlüğünün) bulunmaması gibi başlıkları söyleyebiliriz.

Gerek Gazi Üniversitesi SHMYO kuruluşunun 20. yılı nedeniyle hazırlanan "Geçmişten Geleceğe Sağlık Teknikerliği" kitabında dile getirilen düşünce ve öneriler dikkate alındığında (11) ve gerekse üç yıl ardışık olarak düzenlenen SHMYO Sempozyumlarının sonuç bildirgeleri $(9,13,14)$ karşılaştırmalı incelendiğinde altı çizilen konular arasında akademik iyileştirme ve bilimsel, eğitsel gelişme, yönetsel ve teknik konular öne çıkmaktadır. Sempozyumlara "bütüncül bir yaklaşımla" bakıldığında, geleceğe ve toplumsal gerçeğe uyumlu iyileştirmeler isteyen, ulusal standardizasyon ve akreditasyonu önemseyen, akademik ve eğitsel konularda "yenilenmeyi kaçınılmaz gören" ulusal SHMYO'ları eğitim kadrosunun taşıdığ 1 , canlı tuttuğu "iyimser ortak irade" hep var olmuştur. Fakat ne yazık ki, bazen pasif, bazen reaktif özellikleriyle sürüp gelen ve katlanarak büyüyen bu "iyimserlik" hiçbir türlü üst yönetim katlarında ve karar süreçlerinde etkin olamamış, taşıdığ potansiyel sosyal değer paydaşlarca tam anlaşılmamış ve çağın gereklerine, toplumun beklentilerine göre var olamamıştır. Türkiye'de, diğer Meslek Yüksekokulları (MYO)'nda olduğu üzere, SHMYO'larında da öğrenci, eğitimci ve yöneticileriyle Türkiye Yükseköğrenim Sistemi içinde önemli bir çoğunluğu oluşturan SHMYO'ları "hak ettiği ilgi ve desteği" görememiştir $(15,16)$.

Türkiye'de "klasik" (diğer adıyla teknik) MYO'larında olduğu üzere, SHMYO’larında da eğitim ve "özellikle yönetim" hizmetleri özveriye dayalı çabalar iyi niyetli olarak süregelmiştir. Bu bağlamda, çeşitli aşamalarda alınan yönetsel kararlar yeterince desteklenmemiş, uygulamaya konulamamıs ve SHMYO'larda konuyla ilgili sorunların çözümünde ulusal standartlarda birleşmeye, öğretim izlencelerini güncellemeye (örneğin ÇEP çalışmalarını başlatmaya) uluslararası akreditasyonda buluşmaya 10 yıllık süreçte bir türlü ulaşılamamıştır. Diğer taraftan, Ulusal düzeyde toplanan ve "Türkiye MYO'ları meselelerinin görüşüldüğü” II. Ulusal Meslek Yüksekokulları Müdürler Toplantısı, Sonuç Raporunda bile SHMYO'ları hala "diğer MYO'lar" kategorisinde değerlendirilmiş ve 6. Komisyon raporunda veya genel değerlendirmeler kısmında yönetsel, teknik ve eğitsel sorunların dışında, SHMYO'ları hakkında yakın, orta veya uzak geleceğe ilişkin stratejik bir öngörü veya yol haritasına yer verilmemiştir (17). İlginçtir, aynı ulusal MYO'ları toplantısında (17) "ders programları ile ilgili konuların" görüşüldüğü 5. Komisyon raporunda "YÖK bünyesinde eğitim programlarıyla ilgili tüm gereksinimleri yönlendirecek, güncellemeleri yapacak, gelişmeleri izleyecek bir Çekirdek Eğitim Programlarını (ÇEP) Gelişstirme Komisyonu kurulması" önerilirken, benzer öneriye 6. Komisyon raporunda yer verilmemiștir. Bu bağlamda, SHMYO'ları adına "I.Ulusal Sağlık Hizmetleri Meslek Yüksekokulları Sempozyumu" düzenlenmesi ve sağlık alanında içerik ve nitelik tartışılması ayrıca bir önem taşımaktadır.

Tarihsel olarak 2500 yıldan fazla geçmişe sahip olan ve bugünlere kadar "Sürekli Tıp Eğitimleri" sayesinde dinamik kalmayı başarıp, deneyimlerini güncelleyen ve her zaman kararlı ve örgütlü olarak, insanlığa sağlık hizmeti sunan hekimler ve hekimlik hizmetleri günümüze kadar sürüp gelmiştir. Fakat dünyada veya ülkemizde ortaya çıkışları, varlık nedenleri sağlık hizmetlerinde hekimlere yardım etmek olan "Sağlık Teknikerlerinin" (diğer adıyla nitelikli sağllk insan gücü'nün) eğitimi ve yönetimi bu tarihsel yolculukta arzulanan ölçekte gelişememiş, hak ettiği sosyal tanınırlık, kabul ve saygı görme düzeyini ve ulusal ve/veya evrensel kalite standardını yakalayamamıştır (16). Sevgi çiçeğinin yaşamaya direndiği Orta Anadolu topraklarında (Gölbaşı'nda) 2006'da başlayan Sağllk Meslekleri ve meslektaşları arasındaki bilimsel "ortak akıl paylaşımı” ve insani ilişkiler 2008 Haziran'ından 2015 
Eylül'üne kadar geçen sempozyumsuz 7 yılda eskimeye yüz tutmuş, iletişim zincirleri kopma noktasına gelmişti (16). Mesleki deneyim paylaşım zincirleri tam kopuyordu, "bilgi köprüleri” çöküyordu ki, değerbilir bazı eğitimciler ile sağlik meslekleri eğitiminin "stratejik öneminin" farkında olan az sayıdaki akademisyen iletişime geçerek (18), elektronik ortamda bir araya geldiler. Bu bağlamda, meslekler ve disiplinler arası dayanışmanın potansiyel gücüne önem veren, sağlık eğitimine nitelik kazandırmanın insanlık sorumluluğu olduğu bilincini taşıyanlar; bu bilinç ve sorumlulukları "ortak akıl hareketine" dönüştürmenin kaçınılmaz çağdaş zorunluluk olduğunu gören özverili bazı SHMYO yöneticileri, yeni bir başlangıca öncülük etme fedakârlığında bulunarak, kalite ve standart arayışııın fitilini ateşlediler. Bu öncü ve fedakâr yöneticiler arasında özellikle ve öncelikle Atatürk Üniversitesi SHMYO Müdürü Sayın Prof. Dr. Nuri Bakan ve Müdür Yardımcısı Prof. Dr. Necati Utlu, Kocaeli Üniversitesi SHMYO Müdürü Yrd. Doç. Dr. Rüştü Taştan, Marmara Üniversitesi SHMYO Müdürü Doç. Dr. Meral Yüksel ile aynı SHMYO'da Öğretim Üyesi Prof. Dr. Nusret Erdoğan, Çukurova Üniversitesi SHMYO Müdürü Prof. Dr. Neslihan Boyan ve Dokuz Eylül Üniversitesi SHMYO'nun bir önceki Müdürü Prof. Dr. Atilla Akkoçlu'nun adını anmazsak, eğitim tarihine not düşmezsek "öncülük" kavramına haksızlık, fedakâr ustalara saygısızlık etmiş oluruz.

Birinci SHMYO Müdürleri Çalıştayı sürecinde ve sonrasında çok değerli katkıları olan ve emekleriyle her zaman saygıyla anılmayı hak eden, yukarıdaki öncü yöneticiler sayesinde Türkiye'nin dört bir yanına serpilmiş, 100'ü aşkın SHMYO eğitimcileri arasında mesleki bilgi paylaşımı ve yeniden "ortak akıl kullanımı" için firsat doğmuştur. SHMYO Müdürleri Çalıştayının öncüleri ve katılımcıları arasında "iletişim köprüleri” kurulup, konular irdelendikçe, sürüp gelen ortak sorunların toplumsal gelecek için ciddi tehdit oluşturduğu gerçeği anlaşıldıkça, iletişim kanalları sayesinde bu "yanlış gidişe dur" denmiş ve kopmakta olan "zincirler" güçlendirilmiş (16), "uyuyan sessiz dev" uyandırılmıştır. "İyiliksever eğitim emekçileri, sağlık eğitimi gönüllüleri” Nisan-Mayıs baharında kardelenlerin henüz açtı̆̆ı, doğanın canlandığı, arıların kır çiçeklerinden nektar toplama işbirliği ve dinamizminden esinlenip, harekete geçmişler, güzel bir Eylül sonbaharında (18-19 Eylül 2015'de) Doğu Anadolu'nun incisi, kahraman Nenehatun (19) diyarında buluşmuşladır. Güzel Türkiye'mizin doğusunda, yüce Palandöken dağlarının eteklerinde yüzyıllardır var olan, doğa ve tarih kenti Erzurum'da birinci SHMYO Müdürleri Çalıştayını hayata geçirmişler ve çağı sorgulayan, gelecek için nitelik ve kalite arayan, evrensel dinamiklere uyumu hedefleyen yeni bir Sağllk Meslekleri Ĕgitimi için "işbirliği ve paylaşım hareketini” başlatmışlardır (20).

Atatürk Üniversitesi'nin bulunduğu serhat şehir Erzurum'da gerçekleşen, Sağlik Hizmetleri Meslek Yüksekokullarının eğitim-öğretim sorunlarının görüşülüp tartışıldığ1 birinci SHMYO'ları Müdürler toplantısının sonuç bildirgesine göz attığımızda;

"En önemli kaynak insan, en önemli yattrum ise eğitim'dir. İnsanın etkin ve verimli olabilmesi ancak kapsamlı bir eğitim-öğrenim tasarımı ile gerçekleştirilebilir. Bunu sağlayacak bir eğitim tasarımı ise uluslararası uyuтu, sektörün beklentilerini, mesleki yeterliliği gözeten ve ulusal düzeyde standardı koruyan bir eğitim ile yaşama geçirilebilir. Mesleğinin gerektirdiği bilgi, beceri ve uygulama yeteneklerini kazanmış, değişen şartlara uyum sağlayabilen, çevresi ile etkin iletişim kurabilen, üretken, sorunları fark edip, çözümler getirebilen, ekip içerisinde çalışma becerisi kazanmış insanın, hem kalkınmanın itici gücü hem de uluslararası alanda var olmak için bir gereklilik olduğunu biliyoruz." vurgusuyla başlayan metinde toplantıya "Atatürk Üniversitesi Sağlık Hizmetleri Meslek Yüksekokul Müdürü Prof. Dr. Nuri Bakan başkanlık etmiştir.” ifadesine yer verilmektedir. Toplantı görüş ve kararlarının ayrıntılarına (http://saglikcalistayi.org/1calistay-sonuc-bildirgesi/) bağlantısından erişilebilir (20).

Türkiye'de uzun yıllardır yapılamayanı yapmak için biraraya gelen paydaşların, tarafların ÖSME'ne yönelik güncel mesleki sorunları tartı̧̧mak ve geleceğe yönelik bir yol haritası hazırlamak amacıyla "ortak düşüncede" buluşmaları her türlü övgüye layıktır. "Memleket meselesi" olan bu önemli mesleki/bilimsel toplantıya ilişkin kararlarının ve çözüm önerilerinin yer aldığı Çalıştay Sonuç Bildirgesinin kapsamı 13 sayfadan oluşmaktadır. Bildirgede "Bir sonraki Sağllk Hizmetleri Meslek Yüksekokulları Müdürler toplantısının (2. Çalıștayın) Harran Üniversitesi Sağlık Hizmetleri Meslek Yüksekokulu ev sahipliğinde Nisan/Mayıs 2016'da Şanlıurfa'da gerçekleştirilmesine," diye karar verilmiştir (20). Ayrıntıları bildirgede yer alan, katılımcıların büyük çoğunluğunun hazır bulunduğu kapanış oturumunda alınan önemli karar ile Harran Üniversitesi SHMYO Müdürü Prof. Dr. Hasan Akan'ın göstermiş olduğu ev sahipliği, isteği ve içtenlikli daveti açıkça şunu söylüyordu: İlgisizliklerle geçmiş, dağınıklıktan biraya gelinememiş 7 yılda, kimsesizliğe itilmiş Türkiye ÖSME yeniden sorgulanıyordu. ÖSME'nin geleceği için çok 
önemli umutlar vaat eden, nitelik ve işbirliği için yeni bir eğitsel, yönetsel mesleki dayanışma, yeni bir ortak düşünce hareketi başlamaktaydı.

Bilimsel arşiv kayıtlarına göre, 3. Ulusal SHMYO Sempozyumu, turkuaz renginin hâkim olduğu Van gölü kıyısındaki Yüzüncü Yıl Üniversitesi SHMYO'nun ev sahipliğinde ve çok geniş katılım ile 18-22 Haziran 2008'de gerçekleşmiş, Sağlık Meslekleri Eğitimi ile ilgili önemli sorunlar tartışılmıştı. Fakat önemli sayıdaki akademik bildirilerle zenginleştirilmiş olarak gerçekleşen 3 . Ulusal SHMYO Sempozyumunun (14) devamı gelmediğinden, sosyokültürel paylaşımlar eskimeye, bireyler arası diyaloglar kopmaya başlamıştı. Böylece, sağlık eğitimcileri arasında işbirliği ve ÖSME ile ilgili "ortak akademik kültür yaratma" çabaları kayıp olmaya yüz tutmuş, eğitsel etkileşim ve iletişim "zincirleri” kopmuş ve çok uzun yllara dayanan mesleki birikimleri ve deneyimleri geleceğe taşıyan "ortak kültür köprüleri” de kısa sürede çökmüştü. Bir bakıma 2006'dan beri ortak kararlarla el değiştiren, el değiştirdikçe parlaması ve renklenmesi umulan "SHMYO sempozyumları flaması" kaybolmuştu. Van'dan sonra yere düşmek gibi bir "talihsizlik" yaşayan flamamız, Erzurum'da sorumluluklarının bilincinde olan sağlık eğitimi yöneticilerince yeniden örülmeye başlanmış ve içinde paha biçilmez insani değerler barındıran ÖSME flaması ortak çabayla yeniden göndere yükseltilmişti. Böylece, Nenehatun diyarından yükselen yenilenme ve birlik güneşi dördüncü Ulusal SHMYO Sempozyumuna giden yolu aydınlatmaya ve bilimsel dayanı̧̧ma ruhunu Marmara Üniversitesi SHMYO ev sahipliğinde İstanbul'da yeniden canlandırmaya başlamıştı.

İnsanlık tarihinde önemli bir yeri bulunan, yüzyıllarca tarih, medeniyet ve kültürlere ev sahipliği yapmış, arkeolojik verilere göre tarımın başkenti olan, "peygamberler şehri” Şanlıurfa'daki Harran Üniversitesi SHMYO Müdürlüğü Türkiye'nin dört bir yanında bulunan bütün üniversitelere 2. Çalıştay davetiyelerini göndermişti. Türkiye'de ÖSME bakımından çok önemli bir gelişmeye katkı sunmanın haklı övüncüyle Prof. Dr. Hasan Akan çalıştay davetiyesinde "Sağlık Hizmetleri Meslek Yüksekokulları'nın ülke ihtiyaçlarına göre ĕgitim programlarının geliştirilmesi ve standardizasyonu, mesleki görev tanımlarının yapılmast, program açma ve ögrenci alma kriterlerinin belirlenmesi gibi önemli konularda birleşmek amacıyla, 12-14 Mayıs 2016 tarihleri arasında Harran Üniversitesi'nin ev sahipliğini yapacağı ve ülkemizdeki devlet ve vakıf üniversitelerinin SHMYO'larının yönetici, temsilci ve akademisyenlerinin katılacağı "Sağllk Hizmetleri Meslek Yüksekokullarında Uygulanan Programlarin Güncellenmesi ve Eğitim Standartlarının Belirlenmesi Çalıştayl-II" isimli toplantıya katılmayı ve katkı sunmayı bekliyordu (20). Muhteşem Atatürk barajı kıyısında, doğanın her türlü güzelliklerini sergilediği bir ilkbahar ayında, 12-14 Mayıs'ta, Şanlıurfa'da DSİ Konferans salonunda gerçekleşen 2. SHMYO Müdürleri Toplantısı ve "Sağllk Hizmetleri Meslek Yüksekokullarinda Uygulanan Programlarm Güncellenmesi ve Eğitim Standartlarının Belirlenmesi Çalıştayı-II" mesleki eğitim toplantısı başlamıştı. SHMYO Müdürleri Toplantısı programına http://saglikcalistayi.org/ calistay-programi-11mayis.pdf bağlantısından ve çalıştay sonuç bildirgesinin tam metnine http://saglikcalistayi.org/ sonuc-bildirgesi-2.pdf bağlantısından erişebilirsiniz (22). Ülkemizdeki ÖSME ile ilgili önemli konuların incelendiği çalıştayın 2. oturumunda tarafımca sunulan "Türkiye'de Önlisans Sağlık Meslekleri Eğitiminin Güncel Sorunları ve Gelecek İçin Çözüm Önerileri” sözlü bildirisinde (23) vurgu yapılan bazı çözüm önerilerine bu yazının sonuç kısmında yer verilecektir.

Şanlıurfa'da gerçekleştirilen bu 2. Çalıştayda, katılımcılarının büyük bir çoğunluğunun hazır bulunduğu kapanış oturumunda alınan kararlardan biri çok önemliydi ve hemen herkes yeni gelişmelere yönelmekte hemfikirdi. Çünkü Türkiye SHMYO'ları eğitici ve yöneticilerinin katıldığı bilimsel bir toplantıda ilk defa ve diğer MYO'larından farklı olarak ÖSME için "Sağlık Hizmetleri Meslek Yüksekokulları Programlarına Yönelik Çekirdek Eğitim Programı (ÇEP) Çalıştayı" yapılması gündeme alınıyor ve SHMYO'larda bulunan 37 farklı mesleki eğitimi kapsayan konular ulusal ÖSME-ÇEP (Önlisans Sağllk Meslekleri Eğitimi-Çekirdek Eğitimi Programı) standardı oluşturulması için tartışmaya açılıyordu. Tıpkı Eleanor Roosevelt'in "Başkalarının hatalarından ders çıkarın. Hepsini kendiniz yapmaya yetecek kadar uzun yaşayamazsını." sözüyle dile getirdiği gibi, bizler de 2500 yıllık geçmişe sahip, engin deneyimleri bulunan tıp eğitiminin "süreklilik" özelliğinden yararlanıyor, onların mesleki dinamiklerinden dersler çıkarıyor, SHMYO'larının geleceği için yeni bir yol haritası tasarlıyor, kalite için uğraş veriyoruz. Bu bağlamda, İstanbul Bezmialem Vakıf Üniversitesi SHMYO Müdürlüğünün ev sahipliğinde 11 Kasım 2016'da gerçekleştirilen "1. Sağllk Hizmetleri Meslek Yüksekokulları Çekirdek Eğitim Programı (ÇEP) Çalıştayı" (24) taslak kararları daha geniş katılımla incelemeye açılmıştır. Taslak haldeki ÇEP metinlerini Türkiye'deki bütün SHMYO eğitimcilerinin incelenmesini sağlamak 
amacıyla Çukurova Üniversitesi SHYO Müdürlüğü tarafından kapalı bir iletişim portalı oluşturulmuş ve kullanıma sunulmuştur (25).

Türkiye Yükseköğreniminde, SHMYO'ları bakımından bir ilk olan ve ulusal ölçekte katılım beklenen "Sağllk Hizmetleri Meslek Yüksekokulları Programlarına Yönelik Çekirdek Eğitim Programı (ÇEP) Çalıştayı-II" Çukurova Üniversitesi SHMYO Müdürlüğünün ev sahipliğinde 2426 Nisan 2017'de Adana'da gerçekleştiriliyor (26). İlgili çalıştayın programına http://saglikcalistayi.org/davet-2/ bağlantısından erişilebilir. Çukurova Üniversitesinde gerçekleştirecek Çalıştayın ana amacı, düzenleme kurulunun davetinde vurgulandığı gibi; "18-19 Eylül 2015'de Erzurum'da başlayan yeniden canlanma ve çağa uygun yeni düzenlemeler yaparak "ÖSME'de ulusal standartları tanımlama ve tamamlama" çalışmaları ortak düşünceden, ortak eyleme dönüştürülecek ve sorunların çözümü için, önerler raporlaştırılacaktır. Devamında, önerilerin ilgili makamlarca onaylanması, düşünce ve kararların hukuksal/yönetsel kimlik kazanması için YÖK'e sunulması hedeflenmiştir (26).

Diğer taraftan, 2016 yılında SHMYO Müdürleri Koordinasyon Kurulu bir yeni çalışmayı da hayata geçirilmiştir: "Sağllk Hizmetleri Meslek Yüksekokullarının Güncel Sorunları ve Çözüm Önerileri" konulu sözlü bildiri, Türkiye Sağlık Hizmetleri Meslek Yüksekokulları Müdürleri Koordinasyon Kurulu Başkanı ve Çukurova Üniversitesi SHMYO Müdürü Prof. Dr. Neslihan Boyan tarafından Milli Eğitim Bakanlığı, Mesleki ve Teknik Eğitim Genel Müdürlüğünce 24-25 Ekim 2016 tarihlerinde Antalya'da düzenlenen II. Eğitim Kongresinde sunulmuştur. Dolayisıyla, SHMYO Koordinasyon Kurulu bu bildiriyle son 3 yıllık çalışmalarda oluşturulan, kararlaştırılan gelişmeleri ve süregelmekte olan temel sorunları yetkililere SHMYO'ların ortak görüşü olarak aktarmıştır. Bu çalışma ile ve yine ilk defa Türkiye'de ÖSME'ne ilişkin sorunlar hem MEB'nın sayın ilgileri ve yetkililerine ve hem de YÖK Başkanlığı'nın sayın yetkililerine birinci ağızdan anlatılmış, Sağlık Hizmetleri Meslek Yüksekokulları'nın öncelikleri ve sağlık sektöründeki yeri ve gelecekleri, istihdam sorunları vurgulanmıştır (27).

\section{3. Önlisans Sağlık Meslekleri Eğitiminin Ana Sorunları, Geleceği ve Çözüm Önerileri}

Türkiye'de SHMYO'larında kronikleşmiş halde süregelen, maddi ve teknik yetersizlikler, SHMYO'ların açıldığ yerleşim yerlerinden kaynaklanan sosyokültürel ve demografik sorunların yanı sıra, pek çok yönetsel, sosyoekonomik, gelişim ve gençlik psikolojisi kökenli sorunları ve zorlukları bulunmaktadır $(6,15,16,17$, 28). Bununla birlikte, sağlık sistemi içinde taşıdıkları yaygın hizmet potansiyeli, istihdam ve eğitime yönelik toplumsal talep, sosyoekonomik, sosyokültürel beklentiler bu yükseköğretim kurumlarında yürütülen ÖSME'nin devamını zorunlu kılmakta ve ÖSME’nin kendine özgü var olan güncel sorunlarının çözümlenmesi beklenmektedir.

Daha önceki ulusal mesleki toplantılarda $(6,16,23,28)$ dile getirildiği üzere, bu sorunları sıralayarak, önemleri nedeniyle üzerinde durmak, sağllk meslekleri eğitiminin geleceği için vurgu yapmak yerinde olacaktır.

- SHMYO'larında eğitimcilerin akademik yetkinlikleri ve yönetsel sorunlar.

- Öğrenci niteliği kaynaklı tercih, mesleki algı, eğitsel ve sistematik sorunlar.

- Eğitim hizmetlerinde standartsızlık, akreditasyon olmayışı, sorunsal süreklilikten kaynaklanan kurumsallaşma yetersizlikleri ve olumsuz yansımalar.

- Eğitim-öğretim çıtılarının paydaşlarca etkin, objektif ve çok yönlü toplumsal fayda gözetilmeden değerlendirme yapılması.

- ÖSME'nin yeterince sahiplenilmemiş olması ve geliştirilmesinde engeller bulunması.

- Son yıllara kadar ÖSME için "Sürekli Mesleki Eğitim" algısı ve beklentisinin düzenlenmemiş olması ve Ulusal ve Uluslararası standartlara taşınması anlayışından kaçınılmış olması.

- Türkiye'de geniş ve derin sosyoekonomik dinamikleri bulunan Ulusal SME'ni 'önlisans' düzeyinden uluslararası standartlarda Lisans Sağlık Meslekleri Eğitimi (LISSME) düzeyine taşınmamış olması ve bu LİSME konusunun evrensel gelişmelerden uzak tutulmasi.

- Sağlık hizmetlerinin "değişkenliğì” ve dinamizmine uygunluğu gözetilerek, yasal alt yapısı hazırlanmış LISME süreci ile analitik düşünme yeterliliği arttırılmış, modern sağlık hizmetlerinin kalite ve sorumluluğunun farkında; hekim dışı hizmetlerde üstün niteliklerde ekonomik değer üretme bilgi, beceri potansiyeline sahip "Tibbi Teknologluk" veya benzer niteliklere sahip sağlık eğitimine yönelinmemiş olması. 
Eğer, yukarıda dile getirilen sorunlar bağlamında LíSME sisteminin kurulması, Sağlık Meslekleri Eğitiminde ÖSME'den LİSME'ne geçiş yaklaşımı öncelenirse, Sağllk Alaninda Lisans Tamamlama (SALT) diye bilinen ve sonuçları veya 'elde edilecek haklar' bakımından geleceği henüz tam bilinmeyen, istihdam işlemlerinde potansiyel sorunları bulunan uygulamadan kendiliğinden vazgeçilmiş olacaktır.

\section{Gelecek İçin Çözüm Önerileri}

Türkiye'de yaklaşık 35 ylllı geçmişe sahip Önlisans Sağllk Meslekleri Eğitimine ilişkin yukarıda sıralanan sorunların çözümlenmesi ve 'insancıl bir sağlık meslekleri eğitiminin' sağlanması ve ÖSME'nin sürdürülebilir olması, daha sonra LíSME'ne evrilmesi için aşağıdaki öneriler geleceği doğru okumak adına önemsenmeli ve önceliklendirilmelidir.

Türkiye'de SHMYO'da sürdürülmekte olan eğitimin ulusal standartlarını oluşturmak ve akreditasyonu sağlamak amaciyla Ulusal Sağllk Meslekleri Eğitimi Akreditasyon Kurulu (USMEAK) kurulmalı, bu kurul evrensel hedefler doğrultusunda işlevselleştirilmeli ve paydaşlarca her yönüyle desteklenmelidir.

Türkiye'de ÖSME'nin sahiplenilmesi ve kurumsallaşması için paydaşlar bir araya getirilmeli (6) ve Türkiye Sağllk Meslekleri Ĕgitimini Geliştirme, Değerlendirme ve Akreditasyon Derneği (TÜSMEGDAD) kurulmalı ve desteklenmelidir. Bu bağlamda, Şanlıurfa'da yapılan çalıştay (22) tutanakları gözden geçirilerek, toplantıda ilk defa dile getirilen samimi görüşlerin ve dernek kurulması önerilerinin uygulamaya konulması için girişimlere hız kazandırılmalı, süreci yöneten veya katkı sunanlara destek olunmalı, katılım ve paylaşımlar artırılmalıdır.

Benzer şekilde, Türkiye'de SHMYO'ları öğretim elemanlarının akademik çalışmalarının yayınlandığı nitelikli, 'sürdürülebilir' ulusal bir süreli yayının (Türk Sağllk Meslekleri Eğitimi Dergisi-TÜSMED-) yayınlanması için paylaşımcı yeni bir anlayışla SHMYO'ları arasında organik işbirliği yapılmalıdır. $\mathrm{Bu}$ bağlamda, büyük bir özveri ve çabanın ürünü olarak, farklı SHMYO Müdürlüklerince yayımlanmakta olan mesleki dergiler $(29,30,31)$ her türlü takdir ve övgüyü hak etmekteler. Ancak bu ve benzer dergilerin parasal yetersizliklerinin olmas1, yayın standartlarını yükseltecek makale bulunamaması, dergilerin ulusal ve/veya uluslararası alan indekslerinde taranabilme standartlarını taşıyamaması, kısa ömürlü olmaları, bazen yazı bulamamaları gibi beklenen akademik ilgiyi görmedikleri herkes tarafından bilinmektedir. $\mathrm{Bu}$ alanda var olan onca sorunu aşmanın, "sürdürülebilir ve etki değeri yüksek" kaliteli yayınlarla fark yaratabilmenin yolu "yeniden düşünmek" ve kurumlar arası (meslekler arası) işbirliğine gitmek, güç birliği yapmak ve çağın dinamiklerini (21. yüzyılda hızla yaygınlaşan mesleklerarası veya disiplinlerarası yayınlara yönelme eğilimlerini) doğru okumak gerekmektedir. Günümüzde gelişmelerin gerisinde kalmak, kaybetmek veya zamanla kayıp olmak anlamını taşımaktadır. Bu parasal ve emek yönüyle büyük risklerden sakınmanın ve ayakta kalmanın yolu başkalarının deneyimlerinden yararlanmayı gerektirmektedir. Örneğin, bugüne kadar 51 cilt yapmış, yarım yüzyıldan fazladır yayın hayatına devam eden Ankara Mikrobiyoloji Derneği yayını Mikrobiyoloji Bülteni (32) uzun yıllardır hem Index Medicus'da ve hem de Science Citation Index (SCI)'de taranmanın, "Türkçe" var olmanın ve uluslararası kalmanın güzel bir örneğidir. $\mathrm{Bu}$ ve benzeri örnekler dikkate alınmalıdır.

Öncelikle ülkemiz SHMYO'larında önemli eğitim hizmetleri yapan eğitimci ve araştırmacıların bilimsel çalışmalarıyla ayakta kalacağı ve kesintisiz yayınlanacağı öngörülen TÜSMED ulusal standartlarını ve gelişme sürecini tamamlamalıdır. Bu potansiyel ve süreklilik için de mesleklerarası işbirliği kaçınılmazdır. Daha sonra, katılımlarla, bilimsel destek ve sahiplenmeyle varılacak olan Uluslararası arenada boy ölçüşebilir düzeye getirilmiş bir Turkish Journal of Health Professions Education (TJHPE) olarak yayın hayatına devam etmesi için TÜSMED'e onu destekleyenlere firsat yaratılmalı, girişim başlatılmalıdır. Çünkü 21. Yüzyılda, bilimsel gelişim ve yarışta var olmanın, ayakta kalmanın yolu yeni yaklaşımlardan, gelişen yeni paradigmayı (bilgi paylaşımı ve disiplinlerarası işbirliği yönelimlerini) doğru okumak, yenilikleri içselleştirmek ve "işlevselleştirmekten" geçmektedir $(5,33)$.

"Ulusal Sağlık Hizmetleri Meslek Yüksekokulları Sempozyumları (USHMYOS)" sağlık eğitim sektöründe bu alanında hizmet veren akademisyenleri buluşturan, 'akademik bilgi paylaşımı' firsatlarını yaratan, deneyim aktarımlarını geliştirerek, sorunlara "ortak akıl” yaklaşmak için önemli eğitim platformlarıdır. Bu nedenledir ki, 4.sü bu sene Marmara Üniversitesi SHMYO tarafindan organize edilecek olan USHMYOS'larının evrensel bilimsel nitelik ve sürekliliği sağlanmalıdır. 
Türkiye'de ÖSME için uzun yıllardır eksikliği hissedilen ve Yükseköğretim Kurulu'nda, Tip-Sağllk Bilimleri Komisyonu ve diğer Mesleki Teknik Eğitim Komisyonları ile eşgüdümlü çalışacak, sahadan gelen sorunları değerlendirecek Sağllk Hizmetleri Meslek Yüksekokulları Koordinasyon Merkezi (SHMYO-KOMER) kurulmalıdır. SHMYO-KOMER'in gerekliliği ve sağllk eğitimi yönetimindeki rolü, kapsamı, kaliteli ve eşgüdümlü ÖSME'deki stratejik önemi hakkında YÖK'e ve diğer ilgili üst düzey yetkili birimlere gerekçeli bilgi sunulması ve bu alanda planlama yapılması önemlidir, Türkiye ÖSME'nin kalitesi ve sürekliliği açısından gereklidir.

Burada gelecek için söylenebilir ki; Sevgi çiçeği açan tarlalar diyarı (Ankara'dan başlayıp, portakal çiçeği kokan bereketli Çukurova topraklarına -Adana'ya) uzanan 35 ylllık "sağlık meslekleri eğitimi" sürecinde yaşanan tarihsel yolculukta öne çıkarılan "anahtar sözcükler" ve üzerinde yeniden ve ülkesel düzeyde düşünülmesi gereken "önemli konu başlıkları" şunlar olabilir. Diploma programları arasında denklik, eğitim-öğretim uygulamalarında ulusal standart, ulusal ve uluslararası değerlendirme kuruluşlarınca akreditasyon; SHMYO'ları mensuplarının biraraya gelmesini ve güçbirliği yapmasını sağlayacak dernek(TÜSMEGDAD)kurulması, akademik çalışmalarının yayımlanacağı ortak dergi (TÜSMED/ TJHPE) yapılanması öne çıkmaktadır. Bu konularda ulusal ve/veya uluslararası örneklerin incelenmesi hedefe ulaşmayı, başarı kazanmayı sağlayacaktır.

Özetle söylemek gerekirse; ÖSME'nin 35 yıllık geçmişi iyi değerlendirilmeli, başarısızlıklardan, ilgisizlik veya iletişimsizliklerden ders çıkarılarak 21. Yüzyıl dinamikleri doğru değerlendirmeli. Teknolojik gelişmeler ve iletişim yolları etkin kullanılarak Sağlık Teknikerlerinin (yakın gelecekte Trbbi Teknologların) eleştirel düşünce sistemiyle becerikli ve donanımlı yetiştirilmesi için; ÖSME sözel değil, uygulamalı, etkin ve dinamik olmalıdır. Durağan değil, yenilenen, değişen olmalıdır. ÖSME mezunları yetkin, aranan ve mensuplarına saygı duyulan olmalıdır. Günümüz gelişmelerine göre yüksek kaliteli, sosyokültürel donanımlı ÖSME, sadece 'memleket meselesi' değil, aynı zamanda uluslararası standartlarda 'insanlık meselesi' olarak görülmeli ve desteklenmelidir. Yirmibirinci yüzyılda 'stratejik yatırım alanı' olarak görülen ve tercihen öne çıkan sağlık sektörü, Türkiye'de ÖSME’nin taşıdığı bu potansiyeli iyi değerlendirmelidir. Sağlikta yenilikçilik ve kazanım için, çağdaş nitelikleri taşıyan, dinamik, saygı duyulan bir ÖSME yaklaşımı her yönüyle desteklenmelidir.
Hizmetlerde gerçek kalite, maliyetlerde ekonomik kazanım ve 'insanc1l bir sağlık hizmeti' ancak eğitilmiş, değer verilen sağlık çalışanlarıyla mümkündür. Bu nedenle, Goethe'nin deyimiyle söylenebilir ki; "Bilmek yeterli değildir; uygulamaliylz. İstekli olmak yeterli değildir; yapmallyız."

Küreselleşme fenomeninin egemenlik kurduğu, hızlı yeniliklerin yaşandığı 21. yüzyılda, eğitim teknolojilerinin önlenemez değişimine adım uyduramamak, çağın gereksinmelerine kayitsız kalmak, 'stratejik gelecekte' geri kalmışlık ve milli gelirde ekonomik kayıp, sektörel rekabette devre dışı kalmak demektir. Türkiye'de, ÖSME'nin stratejik geleceğinden kaybetmemek için, yenilikçilik ve yetkinlik yarışında devre dışı kalmamak için, ulusal ve uluslararası standartlarda sağlık eğitim hizmetlerini sürekli kılmak için işbirliği kaçınılmazdır. Güzel ülkemizin yaşayan sosyokültürel değerleriyle özdeşleşmiş sevgi çiçeği diyarı Anakara'dan yola çıkan Ulusal SHMYOS flamasını yere düşürmeden, kültürel kahramanımız "İnce Memed'in" (34) diyarı olan Çukurova'nın bereketli topraklarında rengârenk açan portakal çiçeği tarlalarının bulunduğu Adana'ya taşımak için çalışmak, güçbirliğini, gönül zenginliğini yüceltmek vazgeçilmezdir. Bu zenginlik ve sosyal değerleri yarınlara taşımak, insan sermayemiz ve geleceğimiz olan öğrencilerimize, gençlerimize aktarmak her türlü takdirin ötesinde ve paha biçilmezdir. Eğer 21. yüzyıl dinamikleri, sosyokültürel, ekonomik, iletişim ve bilişim teknolojilerinin değişim hızı doğru okunmaz ve süregelen çekimserlik, ilgisizlik, standartlaşmayı görmezden gelme algı ve anlayışı var olmaya devam ederse; geçmiş 35 yıllık sürecin getirdiği mesleki deneyim ve birikimler yok olmaya, olası yakın ve uzak gelecek planları ise durdurulamayan "değişim kasırgasıyla" yıkılmaya mahkûmdur.

Sonuç olarak, Türkiye'nin geleceği için "sosyal-strateji” ve sağlık ekonomisi bakımından yaygın öneme sahip ÖSME sorunlarının çözümüne giden yol, mesleklerarası yeni eğitim işbirlikteliklerinden, evrensel gelişmeleri değerlendirmekten, daha etkin ve yetkin bir tutumla yeni dinamiklere yönelerek, yönetim ve organizasyon yaklaşımlarını güncellemekten geçmektedir. ÖSME sorunlarının çözüm yolu, nitelik ve verimlilik bakımından tam donanımlı, yetkin sağlık insangücü ile "insancıl sağlık hizmetleri sunulması" için eleştirel düsünce eğitimine (35) ve öğretim programlarına işlevsellik kazandırmaktan geçmektedir. Bu bağlamda, eleştirel düşünce öğretimi ÖSME sürecinde ve sonrasında sağllk hizmetlerinde kalite ve toplumsal gönencin itici gücü ve sağlı alanında bireysel, kurumsal ve sektörel saygınlığın ve sosyoekonomik kazancın altın anahtarı olarak düşünülmelidir. 


\section{KAYNAKLAR}

1. WHO: Framework for Action on Interprofessional Education and Collaborative Practice, 2010; http://www.who.int/hrh/ resources/framework_action/en/ (Erişim tarihi: 14.3.2017)

2. NAM (National Academy of Medicine); Health Professions Education: A Bridge to Quality, 2003, https://www.nap.edu/ catalog/10681/health-professions-education-a-bridge-toquality (Erişim tarihi: 4.3.2017)

3. Anonim: Hacettepe Üniversitesi, Sağlık Hizmetleri Meslek Yüksekokulu Tarihçesi.

http://www.shmyo.hacettepe.edu.tr/tarihce.htm (Erişim tarihi: 4.3.2017)

4. Hizel S ve Kumbasar H. Neden Sağlık Hizmetleri Meslek Yüksekokulları Kuruldu. Ankara Üniversitesi Dikimevi Sağlık Hizmetleri Meslek Yüksekokulu yıllığı C.1, S.1, 2000. http://dergiler.ankara.edu.tr/dergiler/28/39/336.pdf (Erişim tarihi: 4.3.2017)

5. YÖK: Meslek Yüksekokulu Tanımı: 2547 sayılı kanunun (Değişik: 13/2/2011-6111/170 md.) 3/1 maddesi. http:// mevzuat.basbakanlik.gov.tr/Metin.Aspx? MevzuatKod= 1.5.2547\& Mevzuatlliski $=0 \&$ sourceXmlSearch (Erişim tarihi: 4.3.2017)

6. Taştan R.:'Türkiye'de Önlisans Sağlık Meslekleri Eğitiminin Güncel Sorunları ve Gelecek İçin Çözüm Önerileri”. Sağlık Hizmetleri Meslek Yüksekokullarında Uygulanan Programların Güncellenmesi ve Eğitim Standartlarının Belirlenmesi Çalıstayı-II, Bildiri Kitapçı̆̆ı, 91-92, 2016. http://saglikcalistayi.org/saglik_calitayi_bildiri_ kitabi_12mayis.pdf (Erişim tarihi:4.3.2017)

7. Resmi Gazete: Sağlık meslek mensupları ile sağlık hizmetlerinde çalışan diğer meslek mensuplarının iş ve görev tanımlarına dair yönetmelik. http://www.resmigazete.gov.tr/ eskiler/2014/05/20140522-14.htm (Erişim tarihi: 4.3.2017)

8. YÖK: MYO Program Adları ve Unvanları. http://www.yok. gov.tr/web/guest/icerik//journal_content/56_INSTANCE_ rEHF8BIsfYRx/10279/\%2018626 (Erişim tarihi: 4.3.2017)

9. Anonim: Birinci Ulusal Sağlik Hizmetleri Meslek Yüksekokulları Sempozyumu (SHMYOS) Sonuç Bildirgesi. Gazi Üniversitesi, Sağlık Hizmetleri Meslek Yüksekokulu, 11-12 Mayıs 2006 Gölbaşı, Ankara.

10. Vikipedi: Sevgi çiçeği (Cyanus tchihatcheffii). https:// tr.wikipedia.org/wiki/Sevgi_\%C3\%A7i\%C3\%A7e\%C4\%9Fi

11. Özdil R, Koçkaya A. Sağlık Teknikerliği Eğitiminde İlk Ortakakıl Hareketi: Sağlık Hizmetleri Meslek Yüksekokulları Sempozyumları. s: 1-11. Iç̧inde. Özdil R, Ömeroğlu Y, Koçkaya A, Demirtola H, Gülsayın C, Işıldar GY ve Taban B.(ed.) Geçmişten Geleceğe Sağllk Teknikerliği. Onur Matbaac1lık, 2008. Ankara.

12. Arslan ŞF, Ancın V. Sağlık Hizmetleri Meslek Yüksekokulu Öğrencilerinin Eleştirel Düşünme Eğilimlerinin İncelenmesi. Uşak Üniv. Sosyal Bil. Derg. 2016 9/2. 7399. http://dergipark.ulakbim.gov.tr/usaksosbil/article/ view/5000161642/5000165044

13. Anonim: İkinci Ulusal Sağlık Hizmetleri Meslek Yüksekokulları Sempozyumu, Sonuç Bildirgesi. Dokuz Eylül Üniversitesi SHMYO, 2-4 Eylül 2007 Doğanbey, İzmir. http://web.deu.edu.tr/shmyo_sempozyum/sonuc.pdf (Erişim tarihi: 4.3.2017)

14. Anonim: Üçüncü Ulusal Sağlık Hizmetleri Meslek Yüksekokulları Sempozyumu, Sonuç Bildirgesi. Sempozyum Kitab1, Yüzüncü Y1l Üniversitesi SHMYO, Van, 18-22 Haziran 2008: s.30-306

15. Günay D., Günay A, Meslek Yüksekokullarına Genel Bir Bakış ve Eğilimler. V.Ulusal Meslek Yüksekokulları Müdürler Toplantısı (Açılış Konuşmasından), Isparta, 0104 Aralı 2010. http://sempozyum.sdu.edu.tr/5myomt/ komrapor.html

16. Taştan, R. Sağlık Meslekleri Eğitiminde Yeni Yaklaşımlar; Ulusal Sağlık Hizmetleri Meslek Yüksekokullarl Sempozyumlarının Dünü, Bugünü ve Geleceği. Birinci Ulusal Sağlık Hizmetleri Meslek Yüksekokulu Müdürleri Çalıştayı, Atatürk Üniversitesi SHMYO, Erzurum, 18-19 Eylül 2015.

17. YÖK: II. Ulusal Meslek Yüksekokulları Müdürler Toplantıs1, Sonuç Raporu, Muğla Üniversitesi, Muğla, 14-15 Nisan 2006.

18. Taştan R. "Sağlık Hizmetleri Meslek Yüksekokulları Sempozyumlarının" devamını getirmek, yeniden ÖSME sorunlarını tartışmak amacına yönelik (Prof. Dr. Necati Utlu ile birkaç kez telefon görüşmesi), Nisan 2015.

19. Vikipedi: Nene Hatun, https://tr.wikipedia.org/wiki/Nene Hatun (Erişim tarihi: 4.3.2017)

20. Anonim: Ulusal Sağlık Hizmetleri Meslek Yüksekokulları Müdürler Çalıştayı Sonuç Bildirgesi. Birinci Ulusal Sağlık Hizmetleri Meslek Yüksekokulları Müdürler Toplantıs1, Atatürk Üniversitesi SHMYO, Erzurum, 18-19 Eylül 2015.

http://saglikcalistayi.org/1-calistay-sonuc-bildirgesi/ (Erişim tarihi: 4.3.2017)

21. Akan H. Harran Üniversitesi SHMYO Müdürü, "Sağlık Hizmetleri Meslek Yüksekokullarında Uygulanan Programların Güncellenmesi ve Eğitim Standartlarının Belirlenmesi Çalıstayı-II" davet mektubu.

22. Anonim: Sağlik Hizmetleri Meslek Yüksekokullarında Uygulanan Programların Güncellenmesi ve Eğitim Standartlarının Belirlenmesi Çalıstayı-II Sonuç Bildirgesi Harran Üniversitesi SHMYO, Şanlıurfa, 12-14 Mayıs 2016. http://saglikcalistayi.org/sonuc-bildirgesi-2.pdf (Erişim tarihi: 4.3.2017)

23. Taştan R. "Türkiye'de Önlisans Sağlık Meslekleri Eğitiminin Güncel Sorunları ve Gelecek İçin Çözüm Önerileri” Sağlık Hizmetleri Meslek Yüksekokullarında Uygulanan Programların Güncellenmesi ve Eğitim Standartlarının Belirlenmesi Çalıstayı-II. Harran Üniversitesi SHMYO, Şanlıurfa, 12-14 Mayıs 2016.

http://saglikcalistayi.org/saglik_calitayi_bildiri_ kitabi_12mayis.pdf (Erişim: 4.3.2017)

24. Anonim: "Sağlık Hizmetleri Meslek Yüksekokulları Programlarına Yönelik Çekirdek Eğitim Programı (ÇEP)Çalıştayı. Bezmialem Vakıf Üniversitesi SHMYO Müdürlüğü, İstanbul, 11 Kasım 2016.

25. Çukurova Üniversitesi SHYO Müdürlüğü tarafından hazırlanan ÇEP tartışma platformu http://shmyo.derneys. com 
26. Anonim: Sağlık Hizmetleri Meslek Yüksekokulları Müdürleri Toplantıs1-III, "Sağlık Hizmetleri Meslek Yüksekokulları Programlarına Yönelik Çekirdek Eğitim Programı (ÇEP) Çalıştayl-II". Çukurova Üniversitesi SHMYO Müdürlüğü, Mithat Özhan Amfisi, Adana, 24-26 Nisan 2017. http:// saglikcalistayi.org/davet-2/ (Erişim tarihi: 6.3.2017)

27. BoyanN,BiliciN."SağlıkHizmetleriMeslekYüksekokullarının Güncel Sorunlarl ve Çözüm Önerileri. ” II. Eğitim Kongresi, Antalya, 24-25 Ekim 2016. Kongre Özet Raporu, http:// mtegm.meb.gov.tr/meb_iys_dosyalar/2017_01/10171149 Kongre_Yzet_Raporu_09.01.2017.pdf (Erişim tarihi: 14.3.2017)

28. Taştan R. IV. Ulusal Meslek Yüksekokulları Müdürler Toplantıs1, 2. Komisyon Taslak Raporları, Karadeniz Teknik Üniversitesi, Trabzon, 5-8 Kasım 2008.

29. Anonim: Ankara Sağllk Hizmetleri Dergisi.

http://editor.ankara.edu.tr/index.php/ashd/index (Erişim tarihi:8.3.2017)

30. Anonim: Sağllk Hizmetleri Meslek Yüksekokulu Dergisi, İnönü Üniversitesi https://cms.inonu.edu.tr/uploads/contentfile/86/files/ vol4sa2.pdf (Erişim tarihi:8.3.2017)

31. Anonim: Firat Sağlık Hizmetleri Dergisi, Cilt:2, Say1:6 (2007)

32. Anonim: Mikrobiyoloji Bülteni (ISSN: 0374-9096) http://www.mikrobiyolbul.org/Default.aspx (Erişim tarihi:8.3.2017)

33. Frenk J, Chen L, et. all. Health professionals for a new century: transforming education to strengthen health systems in an interdependent world. The Lancet, Nov.29, 2010, DOI: http://dx.doi.org/10.1016/S0140-6736(10)61854-5 (Erişim tarihi:6.3.2017)

34. Vikipedi: “İnce Memed" Yaşar Kemal'in birinci baskısı 1955'de yapılan romanında geçen kahramandır.

35. Huang GC, Newman LR and Schwartzstein RM. Critical Thinking in Health Professions Education: Summary and Consensus Statements of the Millennium Conference 2011. Teach and Learn Med, 26(1), 95-102, 2014 